\title{
$\begin{array}{ll}\text { Research Square } & \text { Preprints are preliminary reports that have not undergone peer review. } \\ \text { They should not be considered conclusive, used to inform clinical practice, } & \text { or referenced by the media as validated information }\end{array}$
}

\section{Cadmium and Lead Differentially Affect Growth and Metal Accumulation in Guar (Cyamopsis Tetragonoloba L.) Varieties}

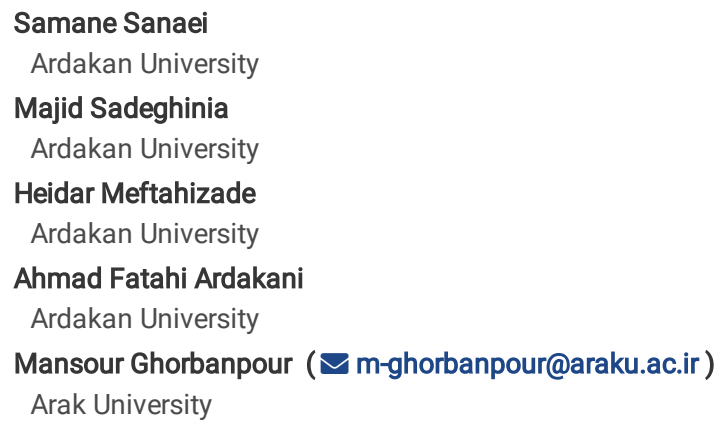

Research Article

Keywords: Phytoremediation, Guar gum, Heavy metal, Uptake.

Posted Date: June 16th, 2021

DOI: https://doi.org/10.21203/rs.3.rs-569558/v1

License: () (7) This work is licensed under a Creative Commons Attribution 4.0 International License. Read Full License

Version of Record: A version of this preprint was published at Environmental Science and Pollution Research on August 17th, 2021. See the published version at https://doi.org/10.1007/s11356-021-15968-y. 


\begin{abstract}
Phytoremediation is a strategy to employ plants to recover high quantities of metals in the soil into the harvestable parts, such as shoots and roots. High levels of $\mathrm{Cd}$ and lead $(\mathrm{Pb})$ in the soil cause several stress symptoms in plants, including a decrease in growth, reduced root growth, and carbohydrate metabolism. In this study, Saravan and HGS-867 as local landrace and Indian guar variety were selected to investigate the effect of the application of Pb (0, 40, 150, and $200 \mathrm{mg} / \mathrm{l})$ and the cadmium $(0,25,50$, and $100 \mathrm{mg} / \mathrm{l})$ on phonological, yield parameters and phytoremediation assessment. The results showed that $\mathrm{Pb}$ translocation factor (TF) was significant in $\mathrm{Pb} \times \mathrm{Cd}$ and $\mathrm{Pb} \times \mathrm{Cd} \times \mathrm{G}$ (genotype) treatments at $1 \%$ and in $\mathrm{Pb} \times \mathrm{G}$ at $5 \%$. $\mathrm{Pb}$ bioconcentration factor (BCF) was significant in all treatments except $\mathrm{Cd}$ and $\mathrm{Cd} \times \mathrm{G}$ at $1 \%$. Mean comparison of the data showed that the number of flowers, leaves, and clusters in plant decreased significantly with increasing $\mathrm{Pb}$ content. With increasing $\mathrm{Cd}$ concentration, the number of branches, height, the number of seeds, clusters, and leaves for each plant decreased significantly at the level of $1 \%$. The maximum TF was observed in Pb at 40 mg/l in the HG-867 variety. Also, the Saravan landrace in $\mathrm{Cd}(100 \mathrm{mg} / \mathrm{l})$ showed the highest amount of BCF (Cd). With increasing the concentrations of $\mathrm{Pb}$ and $\mathrm{Cd}$, the gum percentage decreased significantly. The results of Pearson's correlation analysis indicated that plant height, number of pods/plant, root length, biomass, and pod length had a positive correlation with seed yield and a negative correlation with $\mathrm{TF}(\mathrm{Pb})$ and $\mathrm{BCF}(\mathrm{Pb})$. The results suggest that according to $\mathrm{TF}, \mathrm{BCF}$, and $\mathrm{BAC}, \mathrm{C}$. tetragonoloba L. can be effectively used as a good accumulator.
\end{abstract}

\title{
1. Introduction
}

Heavy metals, like Cadmium (Cd) and Lead (Pb) are particularly toxic to the majority of plants and animals even at low concentrations (Shukla et al., 2007). Heavy metals at their toxic concentration inhibit various stages of plant development, especially seed formation and physiological and biochemical processes. $\mathrm{Pb}$ is the second most dangerous substance, after arsenic, considering the occurrence frequency, toxic effects, and the potential for human exposure. Its transfer from polluted soils to plants has been extremely evaluated, particularly regarding food quality and use in phytoremediation (Uzu et al. 2009). Contamination of the soil with toxic trace metals as well as their accumulation in soil affect agricultural production because of the adverse impacts on crop growth; for example, metal phytotoxicity and soil microorganisms (Nagajyoti et al., 2010). Pb may exit in in soil as a free metal ion and as complexes with inorganic constituents (like $\mathrm{CO}_{3}{ }^{2-}, \mathrm{HCO}_{3}{ }^{-}, \mathrm{SO}_{4}{ }^{2-}$, and $\mathrm{Cl}^{-}$), can exist as organic ligands (such as amino acids and humic acids), or can be adsorbed on particle surfaces (like biological material, peroxides, clay particles, and organic matter) (Uzu et al. 2009). Phytoremediation is a strategy to employ plants to recover high quantities of metals in the soil into the harvestable segments, such as roots and shoots (Mahmood, 2010). Harvesting of the biomass can be safely done using composting, drying, ashing, and strafing at a landfill, pure plant oil manufacturing, anaerobic digestion, microbial, physical, or other chemical means (Ginneken et al., 2007).

High levels of $\mathrm{Cd}$ in the soil can elicit different stress symptoms in plants, like a decrease in growth, particularly root growth, impairments in mineral nutrition, and carbohydrate metabolism (Moya et al. 2004), leading to a reduction in biomass production.

In some earlier reports by Stoyanova and Tchakalova (1999) Cd at toxic levels disturbed the chloroplast envelope as well as the integrity of the membrane system resulting in an increase in plastoglobule number, alteration in the lipid composition, and the levels of the major structural constituents of thylakoid membranes.

Various plant species belonging to the Fabaceae family show phytoremediation potential (Ginneken \& Gawronski, 2007; Anjum et al., 2014). Legumes are rich in phytoremediation and provide additional $\mathrm{N}$-compounds to the soil leading to an improvement in soil fertility and capacity to support biological development (Hao et al., 2014). Cyamopsis tetragonoloba L. Guar (Cyamopsis tetragonoloba L.) is a low-input and annual fast-growing legume species that is almost cultivated in arid and semi-arid areas (Meftahizade et al., 2019). Guar has been recently widely considered because of the general tendency toward the application of polysaccharides from plants in different industrial applications. Guar is a multipurpose crop with economic values cultured for forage, vegetable (green pods), and seed gum that is widely used in various industries, such as food processing (as a novel natural additive), paper manufacturing (as a fiber deflocculants and beater additive), textile and carpet printing, mining explosive, drilling, pharmaceutical, cosmetics, agrochemistry, and oil and gas exploration because of the high galactomannans content of its endosperm (Abidi et al., 2015; Gresta et al., 2017; Mudgil et al., 2014). Guar seed has seed coat (14-17\%), endosperm or gum (35-42\%), and germ (43-47\%) (Sabah El Khir et al., 2008). The demand for guar seed and its derivatives has been recently increased globally.

Guar is fast-growing with a high development rate and shoot biomass. Also, it can be employed for phytoremediation. We investigated tolerance of the landrace (Saravan) and $\mathrm{HG}-867$ variety of guar to $\mathrm{Pb}$ and $\mathrm{Cd}$ treatments in the soil during growth periods.

\section{Materials And Methods}

\subsection{A summary of the site, plant materials, and experimental design}

This experiment was performed in a research greenhouse located in Jahanabad Meybod industrial town. The seeds of Guar (Cyamopsis tetragonoloba L.) were prepared and authenticated from Industrial and Medicinal Plant Research Institute, Ardakan, Iran. Saravan as Iranian landrace and HGS-867 as Indian variety were selected for the current experiment to evaluate the effect of $\mathrm{Cd}$ and $\mathrm{Pb}$ on tested parameters. The study was carried out with three replications of $3 \mathrm{n}$ factorial based on Randomized Complete Design (RCD). The scale of the plot was $9 \mathrm{~m}^{2}(3 \times 3 \mathrm{~m})$. Five seeds were sown per hole, and the plants were thinned to three per hole after two weeks of seeding. The combinations of $\mathrm{Cd}$ nitrate and $\mathrm{Pb}$ nitrate were used. The Pb element was used at four levels $(0,40$, 150 , and $200 \mathrm{mg} / \mathrm{l})$ and the Cd element was used at four levels $(0,25,50$, and $100 \mathrm{mg} / \mathrm{l})$ with three replications.

\subsection{The composition of the soil}


The soil texture was sandy loam $\left(0.87 \mathrm{ds} \mathrm{m}^{-1}, \mathrm{pH} 6.9\right)$ with organic matter content of $8.0 \mathrm{~g} \mathrm{~kg}^{-1}$ soil, field capacity of $26.7 \%$, total nitrogen $\left(\mathrm{N}_{\mathrm{kjel}}\right.$ ahal $)$ of $0.03 \%$, available phosphorus (P) of $14 \mathrm{mg}^{-1} \mathrm{~kg}^{-1}$ soil, and available potassium (K) of $227 \mathrm{mg}^{-1} \mathrm{~kg}^{-1}$. Weeding was performed manually 25 and 50 days after planting (DAP). When plants have four leaves, heavy metal treatments of $\mathrm{Pb}$ and $\mathrm{Cd}$ (each at four levels with three replications) were applied and till harvesting continued.

\subsection{Morphological, phonological, yield parameters and phytoremediation assessment}

Harvest was done at the maturity phase of different landrace and variety. Guar plants were regarded sufficiently mature if the majority of the pods (80\%) were brown, and subsequently, data related to morphological parameters, like plant height (at maturity stage), number of leaves per plant (at pod initiation phase), and leaf area of the plant were recorded from 5 randomly selected plants of each plot.

\subsection{Estimation of photosynthetic pigments}

The chlorophyll was extracted based on the method reported by Arnon (1949). In brief, fresh leaves (1g) were ground with $80 \%$ acetone (20-40 $\mathrm{mL}$ ) and the mixture was subjected to centrifugation (10000 rpm / $5 \mathrm{~min}$ ). The solution absorbance was read at $645 \mathrm{~nm}$ and $663 \mathrm{~nm}$ against the blank (acetone). Total chlorophyll level was determined by the below equation:

Total chlorophyll $(\mathrm{mg} / \mathrm{g} \mathrm{FW})=20.2\left(\mathrm{~A}_{645}\right)+8.02\left(\mathrm{~A}_{663}\right) \times \mathrm{V} / 1000 \mathrm{~W}$

Where $A_{645}$ and $A_{663}$ were the absorbance values determined at 649 and $665 \mathrm{~nm}, \mathrm{~V}$ was the volume of the extract $(\mathrm{mL})$, and W was the weight of the sample (g).

For determining gum\%, the guar flour dry weight achieved following the milling process was determined at $90^{\circ} \mathrm{C}$.

\subsubsection{Phonological parameters}

Phonological parameters, like days to $50 \%$ flowering, days to $50 \%$ podding, and time to start pod harvesting were estimated for two landraces and variety (Patil, 2014).

\subsubsection{Yield and yield components}

Pod length, the number of pods for each plant and each cluster, the number of seeds for each pod and each plant, seed yield, and weight of 100 seeds were determined at harvesting time.

\subsubsection{Evaluation of phytoremediation efficiency (Cd, Pb, BCF, BAC, and TF)}

That plants were oven-dried at $80^{\circ} \mathrm{C}$ for obtaining a constant weight and their dry weights were noted. To determine $\mathrm{Cd}$ and $\mathrm{Pb}$ accumulation in different plant tissues (roots and shoots), harvested plant parts were rinsed completely using tap water, and deionized (DI) water for cleaning the adhered components of soil followed by oven-drying at $80^{\circ} \mathrm{C}$ until reaching a steady weight. $\mathrm{Pb}$ concentration after extraction of samples with $2 \mathrm{~N}$ hydrochloric acid was read using atomic absorption spectrometry. To measure the concentration of $\mathrm{Cd}$ in the shoots and roots of the plant, a sample of the dried plant weighing $2 \mathrm{~g}$ was poured into a porcelain crucible and placed in an oven at $30^{\circ} \mathrm{C}$. The oven temperature was gradually raised to $550^{\circ} \mathrm{C}$ within two hours. After holding for 4 to $12 \mathrm{hours}$ at $550^{\circ} \mathrm{C}$, the oven was turned off and the crucibles were removed from the oven. After cooling, the ash was soaked in a little water and covered with a watch glass, and at the same time, $10 \mathrm{ml}$ of $2 \mathrm{M}$ hydrochloric acid was slowly added. The cruises were then placed in a water bath to release the first white vapors at $80^{\circ} \mathrm{C}$. The contents of the crucible were filtered through Whatman No.1 filter paper into a $100 \mathrm{ml}$ jogger balloon, and after rinsing the crucible, the contents of the jogger balloon were measured. The extract was used to read the concentration of $\mathrm{Cd}$ by atomic absorption spectrometer. For quantifying the $\mathrm{Pb}$ content in the soil, a specimen of $1 \mathrm{~g}$ soil was digested using a wet acid digestion approach through $\mathrm{HNO} 3$ and $\mathrm{HCl}(3: 1)$ followed by heating on a hot plate for $2 \mathrm{~h}$ until observing a clear solution. Following cooling, the volume was completed to $50 \mathrm{~mL}$ through the addition of distilled water. The solution was filtered through Whatman's filter paper and $\mathrm{Pb}$ contents were examined with Atomic Absorption Spectrophotometer.

To evaluate the uptake of $\mathrm{Cd}$ and $\mathrm{Pb}$ in cultivated plants, indices, such as TF and bioconcentration factor (BCF) were estimated (Monni et al., 2000). The TF was determined as a ratio of $\mathrm{Cd}$ and $\mathrm{Pb}$ concentration in plant shoot to that in plant root and the $\mathrm{BCF}$ was obtained from the ratio of $\mathrm{Cd}$ and $\mathrm{Pb}$ concentration in the root to its level in the soil. The bioaccumulation coefficient (BAC) was defined as the $\mathrm{Pb}$ and $\mathrm{Cd}$ ratio in the shoot to that in soil.

\subsection{Data analysis}

The normality of data was assessed by Skewness and Kurtosis test prior to analysis of variance (ANOVA). Differences between treatments were determined using a two-way analysis of variance (ANOVA) by SAS software. The mean analysis was done by Duncan's Multiple Range Test (DMRT). The significant differences were calculated at $p<0.01$. The principal component analysis (PCA) was applied for assessing possible relationships between the treatments by SPSS 10 software. Cluster analysis (UPGMA) using Euclidean distance and scatter plot diagram was done by the PAST software.

\section{Results And Discussion}

According to the ANOVA, plant height was affected by all treatments except $\mathrm{Cd}$ and $\mathrm{Pb}$ interaction at a significance level of $1 \%$. The number of branches per plant was not significant by genotype. But there was a significant difference using other treatments at the level of $1 \%$. The number of flowers and leaves was significant by all treatments, except $\mathrm{G}$ and the interaction of $\mathrm{G}$ (genotype) in $\mathrm{Cd}$ at the level of $1 \%$. The number of clusters per plant was significant in all treatments, but no significant difference was found between the two genotypes at the level of $1 \%$. Chlorophyll content was not significantly affected by Cd and $\mathrm{Pb}$ interaction. Pod length and the number of seeds per plant were also significant by $\mathrm{Pb}$ and the interaction of $\mathrm{Pb}$ and $\mathrm{Cd}$ and $\mathrm{Pb}$ in $\mathrm{Cd}$ at the level of $1 \%$. The 
number of pods/plant and seed yield were also signed by the Pb, G, Pb in G, Pb in Cd, and Pb in Cd in G at the level of $1 \%$. Also, $50 \%$ of flowering was not affected by any of the treatments. However, $50 \%$ of pods showed a significant difference by all treatments except genotype at the level of $1 \%$. The weight of 100 seeds using $\mathrm{Pb}, \mathrm{Cd}$, and $\mathrm{Pb} \times \mathrm{Cd}$ was significantly different at the level of $1 \%$ (Table 1 ). The gum percentage was significantly different only by the $\mathrm{Pb} \times \mathrm{Cd}$ treatment at the level of $1 \%$ and the root depth showed a significant difference using all treatments at the level of $1 \%$.

$\mathrm{Pb}$ TF was also significant using $\mathrm{Pb} \times \mathrm{Cd}$ and $\mathrm{Pb} \times \mathrm{Cd} \times \mathrm{G}$ at $1 \%$ and $\mathrm{Pb} \times \mathrm{G}$ at $5 \%$. Pb BCF was significantly different by all treatments except $\mathrm{Cd}$ and $\mathrm{Cd} \times \mathrm{G}$ at the level of $1 \%$. Cd TF was significantly different by $P b \times C d$ and $P b \times C d \times G$ at the level of $1 \%$. Cd BCF showed a significant difference by $C d, P b \times C d, C d \times G$, and $\mathrm{Pb} \times \mathrm{Cd} \times \mathrm{G}$ treatments, whereas, $\mathrm{BAC}(\mathrm{Cd})$ was not significantly different by any tested treatments, while BAC (Pb) was significantly different by $\mathrm{Pb}, \mathrm{G}, \mathrm{Pb} \times \mathrm{G}$, and $\mathrm{Pb} \times \mathrm{Cd} \times \mathrm{G}$ significant at the level of $1 \%$ (Table 1$)$.

\subsection{Simple impact of $P b, C d$, and genotypes}

Mean comparison of the data showed that the height and number of branches in the control and $\mathrm{Pb}(50 \mathrm{mg} / \mathrm{l})$ treatments showed the highest rate. The number of flowers, leaves, and clusters in the plant decreased significantly by increase in $\mathrm{Pb}$ content. The chlorophyll content was elevated significantly by increase in the $\mathrm{Pb}$ concentration. The pod length and number of seeds per plant in the $\mathrm{Pb}(100 \mathrm{mg} / \mathrm{l})$ treatment had the lowest rate. Regarding the number of pods per plant and seed yield per plant, $\mathrm{Pb}(25 \mathrm{mg} / \mathrm{l})$ treatments had the lowest rate. The weight of 100 seeds in the $\mathrm{Pb}(25 \mathrm{and} 100 \mathrm{mg} / \mathrm{l})$ had the lowest amount (2.01 and 1.77, respectively). Finally, regarding the plant biomass, $\mathrm{Pb}(100 \mathrm{mg} / \mathrm{l})$ treatments showed the lowest level. A reduction in plant biomass can be related to disturbed metabolic activities because of decreased uptake of essential nutrients while growing under Pb stress (Gopal \& Rizvi, 2008; Kopittke et al., 2007). Similar results have been reported by other researchers, Islam et al. 2008 reported that Pb toxicity in Elsholtzia argyi inhibited growth, significantly reduced plant height and root length, reduced fresh and dry weight of shoots, discolored leaves, and folded them. Compared with control treatments, $\mathrm{Pb}$ stress at $1000 \mathrm{mg} \mathrm{kg}^{-1}$ reduced root fresh weight $\left(8.15 \mathrm{~g} \mathrm{plant}^{-1}\right)$ and shoot fresh weight $\left(21.13 \mathrm{~g} \mathrm{plant}^{-1}\right)$ in C. tetragonoloba (Amin et al., 2018).

The gum percentage was also affected by the concentration of $\mathrm{Pb}$. In $\mathrm{Pb}(100 \mathrm{mg} / \mathrm{l})$ treatment, the gum was $32.2 \%$ (Table 2$)$. A reduction in gum in the treatment of high concentration of $\mathrm{Pb}$ may be due to the release of polysaccharides in the pericellular space that largely determines the course of allelopathic processes of sorption, desorption, ion exchange, and cell protection from extreme influences (Lombardi and Vieira, 1999).

The total level of metals accumulated in the shoots is regarded as the most important factor for evaluating the potential of phytoextraction in plants (Zaier et al., 2010). The highest level of BAC (Pb) was observed in $\mathrm{Pb}(25 \mathrm{mg} / \mathrm{l})$. BCF (Pb) increased with increasing the concentration of $\mathrm{Pb}$. In $\mathrm{Pb}(100 \mathrm{mg} / \mathrm{l})$

treatment, the BAC $(\mathrm{Pb})$ was 4.11. The mobility, as well as availability of heavy metals in the soil, are commonly low, particularly when the soil is high in pH, clay and organic matter (Rosselli et al., 2003). Thus, it seems that at the low concentration of these heavy metals, their concentration in soil is so high. The highest $\mathrm{Pb}$ TF from root to shoot was 2.9, 3.7, and 3.54, respectively. This result emphasis that guar can accumulate $\mathrm{Pb}$ in root and can be a good source of $\mathrm{Pb}$ phytoremediation. It seems that $\mathrm{Pb}$ accumulation will occur in the apoplast cell of the root. Kopittke et al. (2007) reported that $\mathrm{Pb}$ reduces the fresh weight of buds in Vigna unguiculata. Also, their examinations using TEM microscopy showed that most of the root Pb accumulates in the apoplast of the outer cell layers of the root. Smaller amounts of $\mathrm{Pb}$ were also observed in the central cylinder apoplast. It was also observed that the amount of $\mathrm{Pb}$ accumulated in the roots is 10-50 times higher than in the buds (Kopittke et al., 2007).

Mean comparison of different levels of $\mathrm{Cd}$ in the studied traits showed that with increasing Cd concentration, height, the number of branches, clusters, seeds, and leaves per plant decreased significantly at the level of $1 \%$. Also, the increase in Cd levels has caused the number of days to $50 \%$ of pods to be increased. However, the maximum days to $50 \%$ pods maturity was observed in the $\mathrm{Cd}$ ( $40 \mathrm{mg} / \mathrm{l})$ ( 51.21 days) (Table 3 ). Root depth and gum percentage also showed a significant decrease with increasing Cd concentration at the level of $1 \%$. Although in $\mathrm{Cd}(40$ and $150 \mathrm{mg} / \mathrm{l})$ treatment, the gum percentage compared with the control showed a significant increase, at $250 \mathrm{mg} / \mathrm{l}$, this rate decreased (31.19\%). Bioaccumulation coefficient (Cd) increased significantly with increasing Cd levels, at $200 \mathrm{mg} / \mathrm{l} \mathrm{Cd}$ and the BAC (Cd) was 3.97 (Table 3). Mihalescu et al. (2010) reported that increasing the concentration of Cd decreased the length of the maize plant, especially at concentrations of 100 and 200 ppm.

Shanker et al. (2005) stated that Pb and Cd that are transferred to the aerial part of the plant, reduce the plant height due to disturbances in the cellular metabolism of the aerial part. The reason for this is the loss of cell dilation and the reduction of mitotic activity or inhibition of cell elongation. Cd in cells inhibits cell proliferation by affecting the cell walls and middle wall and increasing cross-linking between cell wall compounds.

Rai et al. (2005) studied the effects of Cd on Phyllanthus amarus and achieved the following results: Severe fresh and dry weight loss, a decrease in root depth, and a decrease in sugar, carotenoids, protein, and chlorophyll. These findings are consistent with our results. Investigation of different effects of Cd ( 9 , $6,3,3$, and $12 \mathrm{mg} / \mathrm{kg}$ ) on cultivars of Vigna radigna showed that with increasing the amount of $\mathrm{Cd}$, the fresh and dry weight of the plant decreased in all cultivars. But the response of cultivars to weight loss was different (Ghani, 2010), which is in agreement with our finding that varieties have different responses to $\mathrm{BCF}(\mathrm{Cd}$ and $\mathrm{Pb})$. It seems that the reduction of shoot growth due to the effect of $\mathrm{Cd}$ can be due to the reduction of chlorophyll content and photosynthetic activity (Shah et al., 2008).

The mean comparison on the studied variety and landrace showed that HG-867 showed superiority to Saravan landrace in terms of plant height, the number of flowers, seed/ plant, root depth, and BCF ( $\mathrm{Cd}$ and $\mathrm{Pb}$ ). However, gum percentage and biomass in the Saravan landrace were higher than the other variety (36.6\% gum vs. 33.6\%) (Table 4). The current results showed that HG-867 has a stronger accumulator rather than Saravan in the case of Pb and Cd accumulation in roots.

\subsection{Interaction of $\mathrm{Pb}, \mathrm{Cd}$, and genotypes}

The maximum TF $(\mathrm{Pb})$ was observed in $\mathrm{Pb}(40 \mathrm{mg} / \mathrm{l})$ in the HG-867 variety (Fig $4 \mathrm{~A})$. Also, the Saravan landrace in $\mathrm{Cd}(100 \mathrm{mg} / \mathrm{l})$ treatment showed the highest amount of BCF (Cd) (Fig 4B). The HG-867 variety had the highest amount of BAC (Pb) compared with the Saravan landrace in Pb (40 mg/l) treatment (Fig 4C). 
With increasing the levels of $\mathrm{Cd}$, its BAC (Pb) did not increase (Fig 4C). Regarding BCF (Pb), the Saravan landrace in Pb treatment (200 mg/l) showed the highest BCF (Pb) (Fig 4D). Ouzounidou et al. (1995) declared that the uptake of heavy metals can cause chromosomal aberration and division of cells to become unusual that significantly reduced plant growth.

The interaction of $\mathrm{Pb}$ in $\mathrm{Cd}$ in terms of $\mathrm{TF}(\mathrm{Pb})$ showed that $\mathrm{Cd}(100 \mathrm{mg} / \mathrm{l})$ and $\mathrm{Pb}(200 \mathrm{mg} / \mathrm{l})$ had the highest TF (Fig $5 \mathrm{~A})$. Regarding the $\mathrm{BCF}(\mathrm{Pb})$, the results indicated that $\mathrm{Cd}(0)$ and $\mathrm{Pb}(200 \mathrm{mg} / \mathrm{l})$, as well as $\mathrm{Cd}(25 \mathrm{mg} / \mathrm{l})$ and $\mathrm{Pb}(200 \mathrm{mg} / \mathrm{l})$, had the highest BCF (Pb) (Fig 5B). Also, as can be seen in Fig $5 \mathrm{C}$, the highest amount of TF (Cd) was observed in $\mathrm{Cd}(50 \mathrm{mg} / \mathrm{l})$ and $\mathrm{Pb}(40 \mathrm{mg} / \mathrm{l})$ treatments (Fig $5 \mathrm{C})$. in addition, with increasing Cd concentration, the BCF (Cd) increased. The interaction of $\mathrm{Cd}(100 \mathrm{mg} / \mathrm{l})$ and $\mathrm{Pb}(0,40 \mathrm{mg} / \mathrm{l})$ showed the highest amount of BCF (Cd) (Fig 5D).

Regarding the effect of interaction treatments on root length, the results showed that interaction of $\mathrm{Cd}(25 \mathrm{mg} / \mathrm{l})$ and $\mathrm{Pb}$ (control), $\mathrm{Cd}(50 \mathrm{mg} / \mathrm{l}), \mathrm{Pb}$ (control), and $\mathrm{Pb}(150 \mathrm{mg} / \mathrm{l})$ caused the highest root depth $(27,26$, and $25 \mathrm{~cm}$, respectively) (Fig 6A). The interactions of Pb and $\mathrm{Cd}$ regarding gum percentage showed that treatment with $\mathrm{Cd}(25 \mathrm{mg} / \mathrm{l})$ and $\mathrm{Pb}$ (control) $(40$ and $150 \mathrm{mg} / \mathrm{l})$ showed the highest gum percentage (38, 39, and 40\%). However, with increasing the concentrations of $\mathrm{Pb}$ and $\mathrm{Cd}$, the gum percentage decreased significantly (Fig 6B). Regarding biomass trait, with increasing $\mathrm{Cd}$ and $\mathrm{Pb}$, the amount of biomass decreased significantly (Fig $6 \mathrm{C}$ ). Regarding the interaction effect of $\mathrm{Cd}$ and $\mathrm{Pb}$ on seed yield per plant, in control treatments, $\mathrm{Cd}(25 \mathrm{mg} / \mathrm{l})$ and $\mathrm{Pb}$ $(150 \mathrm{mg} / \mathrm{l})$ and $\mathrm{Cd}(100 \mathrm{mg} / \mathrm{l})$ and $\mathrm{Pb}(150 \mathrm{mg} / \mathrm{l})$ were found with the highest amount of seed per plant. By further increasing the concentration of $\mathrm{Pb}$ and $\mathrm{Cd}$, the amount of seed yield in the plant decreased significantly (Fig 6D). Fouda and Arafa (2002) assessed soybeans and reported that treatment with high concentrations of $\mathrm{Cd}$ reduced plant height, number of leaves, and leaf area, while $\mathrm{Pb}$ also caused water stress, thereby reducing leaf area, photosynthesis, plant dry weight, and plant height and it was also effective in reducing the number of nodes.

As can be seen in Fig 3, the maximum weight of 100 seeds was observed in $\mathrm{Pb}(50 \mathrm{mg} / \mathrm{l})$ and $\mathrm{Cd}(150 \mathrm{mg} / \mathrm{l})$ treatments, while the number of branches was more in $\mathrm{Pb}(0) \times \mathrm{Cd}(150 \mathrm{mg} / \mathrm{l}), \mathrm{Pb}(0) \times \mathrm{Cd}(25 \mathrm{mg} / \mathrm{l})$, and control treatments.

Chlorophyll content decreased by the interaction of $\mathrm{Cd} \times \mathrm{Pb}$, especially at high concentrations. It seems that a reduction in protochlorophyllide reductase enzyme activity because of heavy metals toxicity is the main cause for less production of total chlorophyll. Cd can inhibit the photoactivation of photosystemII, which is the main reason for less pigment generation in plants while growing in Cd contaminated soils (De Filippis and Pallaghy, 1994).

A TF greater than 1 indicates that the accumulation in shoots is more than roots and soil, respectively (Marrugo-Negrete et al., 2016). In the current research, $\mathrm{TF}$ in $\mathrm{Cd} \times \mathrm{Pb}$ treatment was more than 1 , which means that guar is a good accumulator of $\mathrm{Cd}$ and $\mathrm{Pb}$ in the shoot. This phenomenon occurs at a high concentration of the used heavy metals.

\subsection{Correlation matrix}

Table 5 lists the results of Pearson's correlation analysis. As shown in this table, plant height, number of pods/plant, root length, biomass, and pod length showed a positive correlation with seed yield, while TF $(\mathrm{Pb})$ and $\mathrm{BCF}(\mathrm{Pb})$ were negative. A gum percentage was another main factor in guar. In the current research, plant height, weight of 100 seeds and pod number showed a positive correlation with gum percentage, while chlorophyll content was found with a negative correlation. there was a negative relationship between the effect of $\mathrm{Cd}$ and the specific surface area of the leaf. Cd reduces water absorption and transpiration, too (Vassilev et al. 1997). Decreased water uptake in Cd-treated plants can be well justified by reducing root growth.

\subsection{Multivariate analyses}

We conducted principal component analysis (PCA) for finding trends in the collected dataset and defining the multivariate relationships between the studied parameters (Table 6). In Tables 6 and 7, the individual values, the percentage of variance, the cumulative percentage, as well as the loading of the components are also given. Only the first four major components (PC1, PC2, PC3, and PC4) were found with values greater than one (6.59, 2.2, 1.95, and 1.38, respectively); thus, data can be divided into four variables comprising $73.21 \%$ of the overall variance.

These high values influence the distinction between landraces, and the high integrity of the relationships observed. In Table 7, the equation of the first four components is shown. The coefficients in this table are ordinary, and thus their numerical values reflect their weight when the corresponding component is formed. The highest coefficients were for the first part, plant height, branch number per plant, number of flower per plant, and number of clusters per plant (Fig. 1).

Cluster analysis (UPGMA) was also conducted through the Euclidean distance coefficient and the average method of linkage based on all the tested traits (Fig. 2) for approximating the relationship between the used treatments. The clusters were divided into two primary clusters (I and II) and two sub-clusters (IA, IB, and IIA, IIB) for $\mathrm{Cd} \times \mathrm{Pb}$ treatment (Fig. 2). For example, $\mathrm{Pb}_{3} \mathrm{Cd}_{1}$ and $\mathrm{Pb}_{3} \mathrm{Cd}_{2}$ were most closely clustered (Fig. 2).

\section{Conclusions}

The BCF, BAC, and TF values are used for identifying the effectiveness of plants for phytoremediation (phytoextraction or phytostabilization) through explaining the accumulation features and translocation behaviors of metals in plants. Plants with BCF, BAC, and TF values $>1$ can be promising phytoextractors, appropriate for phytoextraction, while those with BCF and TF $<1$ are regarded potential. It can be concluded that guar, especially HG-867 variety at high doses of $\mathrm{Pb}$ and $\mathrm{Cd}$ showed values of more than 1 , which indicates that it is effective for translocation and phytostabilization at high concentrations of $\mathrm{Pb}$ and $\mathrm{Cd}$.

\section{Declarations}




\section{Ethical Approval}

This material is the authors' own original work, which has not been previously published elsewhere. Also, the manuscript is not currently being considered for publication elsewhere. This manuscript reflects the authors' own research and analysis in a truthful and complete manner.

\section{Consent to Participate}

All authors have been personally and actively involved in substantial work leading to the manuscript, and will take public responsibility for its content.

\section{Consent to Publish}

All authors have agreed to submit the manuscript in its current form for consideration and possible publication in "Environmental Science and Pollution Research".

\section{Authors Contributions}

S. Sanaei performed the experiment; $M$. Sadeghinia and $\mathrm{H}$. Meftahizade supervised the research, wrote and revised the manuscript; $A$. Fatahi Ardakani and $M$. Ghorbanpour advised the research and contributed to statistical analyses. All authors read and approved the final manuscript version.

\section{Funding}

Not applicable

\section{Competing Interests}

The authors declare that there is no conflict of interest.

\section{Availability of data and materials}

Not applicable

\section{References}

1. Abidi N, Liyanage S, Auld D, Norman L, Grover K, Augadi S, Singla S, Trostle C (2015) Challenges and opportunities for increasing guar production in the United States to support unconventional oil and gas production. In: book: Hydraulic Fracturing Impacts and Technologies a Multidisciplinary Perspective. CRC Press, pp 207-225. https://doi.org/10.1016/j.jngse.2015.12.020

2. Amin H, Arain BA, Jahangir TM, Abbasi MS, Amin F (2018) Accumulation and distribution of lead (Pb) in plant tissues of guar (Cyamopsis tetragonoloba L.) and sesame (Sesamum indicum L.): profitable phytoremediation with biofuel crops. Geology Ecology Landscapes 2(1):51-60. https://doi.org/10.1080/24749508.2018.1452464

3. Anjum NA, Umar S, Iqbal M (2014) Assessment of cadmium accumulation, toxicity, and tolerance in Brassicaceae and Fabaceae plants- implications for phytoremediation. Environ Sci Pollut Res 21(17):10286-10293. https://doi.org/10.1007/s11356-014-2889-5

4. Arnon DI (1949) Copper Enzymes in Isolated Chloroplasts. Polyphenoloxidase in Beta vulgaris. Plant Physiol 24(1):1-15. https://doi.org/10.1104/pp.24.1.1

5. De Filippis LF, Pallaghy CK (1994) Heavy Metals: Sources and Biological Effects. In: Rai LC, Gaur JP, Soeder CJ (eds), Advances in Limnology Series: Algae and Water Pollution. Scheizerbartsche Press, pp 31-77

6. Fouda RA, Arafa AA (2002) Alleviation of cadmium toxicity on soybean, Glycine max (L.) Merr. by inoculation with bradyrhizobium and vesiculararbuscular mycorrhizae or kinetin. Journal of Agriculture Science of Mansoura University 27(11):7385-7403

7. Gawronski SW, Gawronska H (2007) Plant taxonomy for phytoremediation. In: Marmiroli N, Samotokin B, Marmiroli M (eds) Advanced Science and Technology for Biological Decontamination of Sites Affected by Chemical and Radiological Nuclear Agents, vol 75. Springer, Dordrecht. https://doi.org/10.1007/978-1-4020-5520-1_5 NATO Science Series: IV: Earth and Environmental Sciences

8. Ghani A (2010) Effect of cadmium toxicity on the growth and yield components of mungbean [Vigna radiata (L.) Wilczek]. World Applied Sciences Journal 8:26-29

9. Ginneken LV, Meers E, Guisson R, Ruttens A, Elst K, Tack FMG, Vangronsveld J, Diels L, Dejonghe W (2007) Phytoremediation for heavy metalcontaminated soils combined with bioenergy production. Environmental Engineering Landscape Management 15(4):227-236. https://doi.org/10.3846/16486897.2007.9636935

10. Gopal R, Rizvi AH (2008) Excess lead alters growth, metabolism and translocation of certain nutrients in radish. Chemosphere 70(9):1539-1544 https://doi.org/10.1016/j.chemosphere.2007.08.043

11. Gresta F, Wink M, Prins U, Abberton M, Capraro J, Scarafoni A, Hill G (2017) Lupins in European cropping systems. In: book: Legumes in cropping systems. CABI Publishing, pp 88-108. https://hdl.handle.net/10568/82554

12. Hao X, Taghavi S, Xie P, Orbach MJ, Alwathnani HA, Rensing C, Wei G (2014) Phytoremediation of heavy and transition metals aided by legume-rhizobia symbiosis. International journal of Phytoremediation 16(2):179-202. https://doi.org/10.1080/15226514.2013.773273

13. Islam E, Liu D, Li T, Yang X, Jin X (2008) Effect of Pb toxicity on leaf growth, physiology and ultrastructure in the two ecotypes of Elsholtzia argyi. Journal of Hazardous Materials 154:914 926 
14. Kopittke PM, Asher CJ, Blamey FPC, Menzies N (2077) Toxic effects of Pb2 + on the growth and mineral nutrition of signal grass (Brachiaria decumbens) and Rhodes grass (Chloris gayana). Plant Soil 300(1):127-136. https://doi.org/10.1007/s11104-007-9395-1

15. Lombardi AT, Vieira AAH, Sartori LA (2002) Mucilaginonus capsule adsorption and intracellular uptake of copper by Kirchneriella aperta (Chlorococcales). J Phycol 38(2):332-337. https://doi.org/10.1046/j.1529-8817.2002.00126.x

16. Mahmood T (2010) Phytoextraction of heavy metals: The process and scope for remediation of contaminated soils. Soil Environ 29:91-109

17. Marrugo-Negrete J, Marrugo-Madrid S, Pinedo-Hernández J, Durango-Hernández J, Díez S (2016) Screening of native plant species for phytoremediation potential at a Hg-contaminated mining site. Science of The Total Environment 542(A):809-816. https://doi.org/10.1016/j.scitotenv.2015.10.117

18. Meftahizadeha H, Ghorbanpourb M, Asareh MH (2019) Changes in phenological attributes, yield and phytochemical compositions of guar (Cyamopsis tetragonoloba L.) landaraces under various irrigation regimes and planting dates. Scientia Horticulturae 256:108577

19. Mihalescu L, Mare-Rosca O, Marian M, — Bildar C (2010) Research on the growth intensity of the Zea mays L. plantlets aerial parts under cadmium treatment. Analele Universitatii din Oradea Fascicula Biologi 7(1):147-151

20. Monni S, Salemaa M, Millar N (2000) The tolerance of Empetrum nigrum to copper and nickel. Environ Pollut 109(2):221-229. https://doi.org/10.1016/S0269-7491(99)00264-X

21. Moya JL, Ros R, Picazo I (2004) Influence of cadmium and nickel on growth, net photosynthesis and carbohydrate distribution in rice plants. Photosynth Res 36(2):75-80. https://doi.org/10.1007/BF00016271

22. Mudgil D, Barak S, Khatkar BS (2014) Guar gum: processing, properties and food applications- A Review. J Food Sci Technol 51(3):409-418. https://doi.org/10.1007/s13197-011-0522-x

23. Nagajyoti PC, Lee KD, Sreekanth TVM (2010) Heavy metals, occurrence and toxicity for plants: a review. Environ Chem Lett 8(3):199-216. https://doi.org/10.1007/s10311-010-0297-8

24. Ouzounidou G, Ciamporova M, Moustakas M, Karataglis S (1995) Responses of maize (Zea mays L.) plants to copper stress. I. Growth, mineral content and ultrastructure of roots. Environ Exp Bot 35(2):167-176. https://doi.org/10.1016/0098-8472(94)00049-B

25. Patil DV (2014) Genetic variability and sowing dates effect of cluster bean (Cyamopsis tetragonoloba L) genotypes in semi-arid region of Maharashtra. Indian Plant Archives 14:1-6

26. Rai V, Khatoon S, Bisht SS, Mehrotra S (2005) Effect of Cadmium on growth, ultramorphology of leaf and secondary metabolites of Phyllanthus amarus Schum. \& Thonn Chemosphere 61:1644-1650

27. Rosselli W, Keller C, Boschi K (2003) Phytoextraction capacity of trees growing on a metal contaminated soil. Plant Soil 256(2):265-272. https://doi.org/10.1023/A:1026100707797

28. Sabah E, Khir MK, Ishag KEA, Yagoub ABA (2008) Chemical composition and oil characteristics of sesame seed cultivars grown in Sudan. Research Journal of Agriculture Biological Sciences 4(6):761-766

29. Shah FR, Ahmad N, Masood KR, Zahid DM (2008) The influence of cadmium and chromium on the biomass production of shisham (Dalbergia sissoo roxb.) seedlings. Pak J Bot 40(4):1341-1348

30. Shanker AK, Cervantes C, Loza-Tavera H, Avudainayagam S (2005) Chromium toxicity in plants. Environ Int 31(5):739-753. https://doi.org/10.1016/j.envint.2005.02.003

31. Shukla SR, Rao RV, Sharma SK, Kumar P, Sudheendra R, Shashikala S (2007) Physical and mechanical properties of plantation-grown Acacia auriculiformis of three different ages. Australian Forestry 70(2):86-92. https://doi.org/10.1080/00049158.2007.10675007

32. Stoyanova D, Tchakalova E (1999) Cadmium Induced Ultrastructural Changes in Shoot Apical Meristem of Elodea Canadensis Rich. Photosynthetica 37(1):47-52. https://doi.org/10.1023/A:1007014828887

33. Uzu G, Sobanska S, Aliouane Y, Pradere P, Dumat C (2009) Study of lead phytoavailability for atmospheric industrial micronic and sub-micronic particles in relation with lead speciation. Environ Pollut 157(4):1178-1185. https://doi.org/10.1016/j.envpol.2008.09.053

34. Vassilev A, Yordanov I (1997) Reductive analysis of factors limiting growth of cadmium-treated plants: a review. Bulgarian Journal of Plant Physiology 23(3-4):114-133

35. Zaier H, Ghnaya T, Lakhdar A, Baioui R, Ghabriche R, Mnasri M, Sghair S, Lutts S, Abdelly C (2010) Comparative study of Pb-phytoextraction potential in Sesuvium portulacastrum and Brassica juncea: tolerance and accumulation. J Hazard Mater 183(1-3):609-615.

https://doi.org/10.1016/j.jhazmat.2010.07.068

\section{Tables}




\begin{tabular}{|c|c|c|c|c|c|c|c|c|c|c|c|c|}
\hline S.O.V & df & $\mathbf{H}$ & $\mathrm{Br}$ (NO) & $\mathrm{Fl}(\mathrm{NO})$ & Clu (NO) & L (NO) & $\mathrm{CH}$ & L. A & P. L & $S(\mathrm{NO})$ & $P(N O)$ & S.Y \\
\hline Rep & 2 & $67.167^{\mathrm{ns}}$ & $2.260^{\mathrm{ns}}$ & $9317.469^{\text {ns }}$ & $30.406^{\mathrm{ns}}$ & $861.792^{\text {ns }}$ & $54.214^{\mathrm{ns}}$ & $44.667^{\mathrm{ns}}$ & $0.512^{\mathrm{ns}}$ & $1.377^{\mathrm{ns}}$ & $1.766^{\mathrm{ns}}$ & $83.30 !$ \\
\hline $\mathrm{Pb}$ & 3 & $11411.705^{\star \star}$ & $62.010^{\star *}$ & $90674.306^{* \star}$ & $968.083^{\star *}$ & $21682.667^{\star \star}$ & $415.904^{\star \star}$ & $670.944^{\star \star}$ & $4.739^{* *}$ & $7.217^{\star \star}$ & $40.062^{\star *}$ & 2104. f \\
\hline Cd & 3 & $1971.455^{\star *}$ & $36.788^{\star *}$ & $16026.250^{*}$ & $214.972^{\star \star}$ & $6517.056^{*}$ & $162.819^{\text {ns }}$ & $313.028^{\mathrm{ns}}$ & $1.552^{\mathrm{ns}}$ & $3.723^{*}$ & $6.635^{\mathrm{ns}}$ & $425.2 i$ \\
\hline G & 1 & $1211.260^{\star \star}$ & $11.344^{\mathrm{ns}}$ & $315.375^{\mathrm{ns}}$ & $24.000^{n s}$ & $13.500^{\mathrm{ns}}$ & $200.971^{\mathrm{ns}}$ & $280.167^{\mathrm{ns}}$ & $0.66^{\mathrm{ns}}$ & $0.388^{n s}$ & $29.040^{\star \star}$ & 954.44 \\
\hline $\mathrm{Pb} * \mathrm{Cd}$ & 9 & $3001.227^{\star \star}$ & $24.721^{\star *}$ & $22827.916^{\star *}$ & $245.002^{* *}$ & $6583.181^{\star *}$ & $228.985^{\star \star}$ & $279.995^{*}$ & $2.055^{\star *}$ & $3.621^{* *}$ & $13.104^{\star \star}$ & 713.46 \\
\hline$P b * G$ & 3 & $5080.879^{\star \star}$ & $28.820^{\star \star}$ & $43331.500^{\star \star}$ & $444.857^{\star \star}$ & $9973.786^{\star *}$ & $228.448^{*}$ & $342.190^{\star}$ & $2.523^{*}$ & $4.246^{* *}$ & $21.916^{\star *}$ & $1074 . \epsilon$ \\
\hline$C d * G$ & 3 & $1153.569^{\text {ns }}$ & $17.986^{*}$ & $8733.5^{\mathrm{ns}}$ & $132.619^{*}$ & $3493.071^{\mathrm{ns}}$ & $157.058^{\mathrm{ns}}$ & $196.595^{\mathrm{ns}}$ & $1.608^{\mathrm{ns}}$ & $2.644^{\mathrm{ns}}$ & $7.483^{\text {ns }}$ & $361.1 \varepsilon$ \\
\hline $\begin{array}{l}\mathrm{Pb} * \mathrm{Cd} * \\
\mathrm{G}\end{array}$ & 9 & $1606.265^{\star \star}$ & $13.537^{\star \star}$ & $13456.940^{\star \star}$ & $141.526^{\star \star}$ & $3723.564^{*}$ & $145.912^{*}$ & $200.473^{\text {ns }}$ & $1.814^{\star \star}$ & $2.963^{\star \star}$ & $8.356^{\star \star}$ & 438.91 \\
\hline Error & 62 & 117.349 & 3.078 & 4819.877 & 32.223 & 1753.609 & 77.357 & 160.892 & 0.72 & 1.018 & 2.793 & 142.34 \\
\hline \multicolumn{13}{|c|}{$\begin{array}{l}\text { S.O.V.: Source of variation, } \mathrm{H} \text { : height, } \mathrm{Br}(\mathrm{NO}) \text { : Number of branches, } \mathrm{FI}(\mathrm{NO}) \text { : Number of flowers, Clu (NO): Number of clusters, L (NO): Number of leave, } \mathrm{CH} \text { : chlc } \\
\text { Leaf Area, }\end{array}$} \\
\hline D 1. Por & & & & (1). Numb & & Dd vindd 5 & . $50 \% \mathrm{n}$ & & & & & \\
\hline
\end{tabular}

\begin{tabular}{|c|c|c|c|c|c|c|c|c|c|c|c|c|c|}
\hline S.O.V & df & $50 \% \mathrm{f}$ & $\begin{array}{l}\text { W } 100 \\
\text { S }\end{array}$ & B & TSPH & Gum\% & RL & $\mathrm{Pb}$ TF & $\mathrm{Cd}$ TF & BCF Cd & BAC Cd & $\mathrm{BCF} \mathrm{Pb}$ & BA \\
\hline Rep & 2 & $4.667^{\mathrm{ns}}$ & $0.929^{n s}$ & $3.690^{\text {ns }}$ & $11.760^{\mathrm{ns}}$ & $29.729^{n s}$ & $2.260^{\mathrm{ns}}$ & $0.0830^{\mathrm{ns}}$ & $0.0163^{n s}$ & $11.22^{*}$ & $148.11^{\mathrm{ns}}$ & $5.3034^{\mathrm{ns}}$ & 4.8 \\
\hline $\mathrm{Pb}$ & 3 & $60.038^{\text {ns }}$ & $2.332^{* *}$ & $119.967^{\star \star}$ & $603.8^{* \star}$ & $124.987^{\mathrm{ns}}$ & $694.4^{\star *}$ & $0.5109^{\text {ns }}$ & $4.2685^{\mathrm{ns}}$ & $3.778^{\mathrm{ns}}$ & $134.62^{\text {ns }}$ & $51.895^{\star \star}$ & 11. \\
\hline Cd & 3 & $27.955^{\text {ns }}$ & $2.557^{\star \star}$ & $8.545^{\mathrm{ns}}$ & $445.9^{\star \star}$ & $220.775^{\mathrm{ns}}$ & $134.42^{* \star}$ & $0.7380^{\mathrm{ns}}$ & $0.1376^{\mathrm{ns}}$ & $32.65^{\star \star}$ & $148.14^{\mathrm{ns}}$ & $7.3208^{\text {ns }}$ & 1.8 \\
\hline G & 1 & $102.094^{\mathrm{ns}}$ & $0.492^{\text {ns }}$ & $28.276^{*}$ & $187.04^{\star}$ & $218.297^{\mathrm{ns}}$ & $225.09^{* \star}$ & $0.6439^{\text {ns }}$ & $1.7222^{\mathrm{ns}}$ & $4.061^{\mathrm{ns}}$ & $103.02^{\text {ns }}$ & $13.041^{\star *}$ & 30. \\
\hline $\mathrm{Pb} * \mathrm{Cd}$ & 9 & $33.727^{\text {ns }}$ & $1.807^{\star \star}$ & $29.816^{* *}$ & $276.3^{\star \star}$ & $191.022^{*}$ & $196.56^{\star \star}$ & $0.4975^{\star *}$ & $1.6234^{\star \star}$ & $11.52^{\star \star}$ & $129.545^{\mathrm{ns}}$ & $15.878^{\star *}$ & 3.3 \\
\hline$P b * G$ & 3 & $43.546^{\mathrm{ns}}$ & $1.200^{\mathrm{ns}}$ & 57.126 ** & $307.8^{\star *}$ & $107.683^{\text {ns }}$ & $356.70^{\star *}$ & $0.5568^{\star}$ & $2.2207^{\mathrm{ns}}$ & $4.065^{\mathrm{ns}}$ & $127.39^{\text {ns }}$ & $24.657^{\star \star}$ & 11. \\
\hline$C d * G$ & 3 & $41.212^{\mathrm{ns}}$ & $1.39^{\mathrm{ns}}$ & $11.679^{\mathrm{ns}}$ & $253.4^{\star \star}$ & $136.977^{\mathrm{ns}}$ & $120.486^{*}$ & $0.4159^{n s}$ & $0.3638^{n s}$ & $14.87^{\star \star}$ & $132.30^{\text {ns }}$ & $6.073^{\text {ns }}$ & 6.6 \\
\hline $\mathrm{Pb}^{*} \mathrm{Cd}^{*}$ & 9 & $34.287^{\mathrm{ns}}$ & $1.077^{*}$ & $17.522^{\star \star}$ & $159.3^{\star \star}$ & $154.747^{\text {ns }}$ & $124.28^{\star \star}$ & $0.4296^{\star *}$ & $1.2243^{\star \star}$ & $7.219^{\star \star}$ & $125.73^{\mathrm{ns}}$ & $9.0274^{\star \star}$ & 3.6 \\
\hline Error & 62 & 28.290 & 0.536 & 4.988 & 33.051 & 88.609 & 17.798 & 0.2056 & 0.6275 & 2.7669 & 127.571 & 1.9658 & 1.9 \\
\hline \multicolumn{14}{|c|}{$\begin{array}{l}\text { S.O.V.: Source of variation, } 50 \% \text { f: } 50 \% \text { flowering, W } 100 \text { S: Weight of } 100 \text { seeds, B: Biomass, TSPH: Time to start pod harvesting, Gum\%: gum } \\
\text { length, }\end{array}$} \\
\hline \multicolumn{14}{|c|}{ Pb TF: Translocation factor (Pb), Cd TF: Translocation factor (Cd), BCF Cd: Bioconcentration factor (Cd), BAC Cd: Bioaccumulation coefficient (Cd), } \\
\hline \multicolumn{14}{|c|}{ BCF Pb: Bioconcentration factor (Pb), BAC Pb: Bioaccumulation coefficient (Pb) } \\
\hline
\end{tabular}

\begin{tabular}{|c|c|c|c|c|c|c|c|c|c|c|c|c|c|c|c|}
\hline $\begin{array}{l}\mathrm{Pb} \\
(\mathrm{mg} / \mathrm{l})\end{array}$ & $\mathbf{H}$ & $\begin{array}{l}\mathrm{Br} \\
\text { (NO) }\end{array}$ & $\begin{array}{l}\mathrm{FI} \\
\text { (NO) }\end{array}$ & $\begin{array}{l}\text { Clu } \\
\text { (NO) }\end{array}$ & L (NO) & $\mathrm{CH}$ & L. A & $\mathrm{BCF} \mathrm{pb}$ & RL & P. L & B & $\begin{array}{l}P \\
\text { (NO) }\end{array}$ & S. Y & $50 \% \mathrm{p}$ & $\begin{array}{l}\text { W } 100 \\
\text { S }\end{array}$ \\
\hline 0 & $87.1^{\mathrm{a}}$ & $12.5^{\mathrm{a}}$ & $154.4^{\mathrm{a}}$ & $20.4^{\mathrm{a}}$ & $117.96^{\mathrm{a}}$ & $62.5^{\mathrm{ab}}$ & $23.04^{\mathrm{ab}}$ & $0.9247^{c}$ & $25.17^{a}$ & $5.900^{\mathrm{a}}$ & $2.90^{\mathrm{a}}$ & $4.7^{\mathrm{ab}}$ & $34.3^{\mathrm{a}}$ & $50.5^{\mathrm{a}}$ & $6.4296^{a}$ \\
\hline 25 & $47.7^{b}$ & $9.5^{b}$ & $28.5^{\mathrm{c}}$ & $7.5^{\mathrm{bc}}$ & $57.63^{\mathrm{bc}}$ & $60.4^{\mathrm{b}}$ & $15.13^{\mathrm{ab}}$ & $1.122^{\mathrm{bc}}$ & $14.42^{b}$ & $5.092^{b}$ & $2.27^{\mathrm{ab}}$ & $2.8^{\mathrm{c}}$ & $18.3^{\mathrm{b}}$ & $50.0^{\mathrm{ab}}$ & $2.0158^{c}$ \\
\hline 50 & $85.8^{\mathrm{a}}$ & $11.4^{\mathrm{a}}$ & $88.4^{\mathrm{b}}$ & $11.5^{\mathrm{b}}$ & $88.63^{\mathrm{ab}}$ & $67.8^{\mathrm{a}}$ & $22.21^{\mathrm{ab}}$ & $2.117^{b}$ & $21.88^{\mathrm{a}}$ & $5.521^{\mathrm{ab}}$ & $1.85^{\mathrm{b}}$ & $5.8^{\mathrm{a}}$ & $38.2^{\mathrm{a}}$ & $50.7^{a}$ & $4.6942^{b}$ \\
\hline 100 & $49.7^{b}$ & $9.1^{b}$ & $23.0^{\mathrm{C}}$ & $6.4^{\mathrm{c}}$ & $53.63^{c}$ & $69.1^{\mathrm{a}}$ & $12.29^{b}$ & $4.11^{\mathrm{a}}$ & $14.58^{\mathrm{b}}$ & $4.916^{b}$ & $1.11^{\mathrm{c}}$ & $3.7^{b c}$ & $22.8^{b}$ & $49.3^{b}$ & $1.7704^{c}$ \\
\hline \multicolumn{16}{|c|}{$\begin{array}{l}\text { H: Height, Br (NO): Number of Branches, Fl (NO): Number of Flowers, Clu (NO): Number of Clusters, L (NO): Number of Leave, CH: Chlorophyll, L. A: Leaf Area, } \\
\text { Bioconcentration Factor (Pb), RL: Root Length, P. L: Pod Length, B: Biomass, P (NO): Number of pods, S. Y: Seed yield, } 50 \% \text { p: } 50 \% \text { pods ,W 100 S: Weight of } 1 \\
\text { Bioaccumulation Coefficient (Pb), }\end{array}$} \\
\hline \multicolumn{16}{|c|}{ Gum\%: Gum Percentage. } \\
\hline
\end{tabular}




\begin{tabular}{|c|c|c|c|c|c|c|c|c|c|c|c|}
\hline $\mathrm{Cd}(\mathrm{mg} / \mathrm{l})$ & $\mathbf{H}$ & $\mathrm{Br}(\mathrm{NO})$ & S.P (NO) & Clu (NO) & L (NO) & S.Y & $50 \% \mathrm{pd}$ & TSPH & $\mathrm{RL}$ & Gum\% & BAC Cd \\
\hline 0 & $76.17^{a}$ & $11.21^{\mathrm{a}}$ & $6.68^{a b}$ & $14.54^{\mathrm{a}}$ & $90.42^{\mathrm{a}}$ & $33.56^{\mathrm{a}}$ & $49.54^{b}$ & $41.58^{\mathrm{b}}$ & $20.88^{a}$ & $34.9^{\mathrm{a}}$ & $1.662^{b}$ \\
\hline 40 & $72.79^{a b}$ & $11.50^{\mathrm{a}}$ & $6.75^{a}$ & $12.83^{\mathrm{a}}$ & $86.25^{a b}$ & $29.96^{\mathrm{ab}}$ & $49.42^{b}$ & $50.17^{a}$ & $19.88^{a}$ & $38.4^{\mathrm{a}}$ & $1.5628^{b}$ \\
\hline 150 & $65.96^{\mathrm{b}}$ & $11.17^{a}$ & $6.42^{\mathrm{ab}}$ & $11.08^{\mathrm{ab}}$ & $86.25^{\mathrm{ab}}$ & $23.90^{\mathrm{b}}$ & $49.50^{b}$ & $41.79^{b}$ & $19.75^{\mathrm{a}}$ & $36.02^{\mathrm{a}}$ & $1.6981^{b}$ \\
\hline 200 & $55.63^{c}$ & $8.83^{b}$ & $5.88^{b}$ & $7.54^{\mathrm{b}}$ & $54.92^{b}$ & $26.43^{a b}$ & $51.21^{\mathrm{a}}$ & $41.29^{b}$ & $15.54^{\mathrm{b}}$ & $31.19^{b}$ & $3.973^{\mathrm{a}}$ \\
\hline
\end{tabular}

Table 4. Mean Comparison of traits measured in two landrace and variety.

\begin{tabular}{|c|c|c|c|c|c|c|c|c|}
\hline Genotype & $\mathrm{H}$ & $\mathrm{Fl}(\mathrm{NO})$ & S.P & B & Gum\% & RL & $\mathrm{BCF}(\mathrm{Pb})$ & $\mathrm{BCF}(\mathrm{Cd})$ \\
\hline Saravan & $64.1^{b}$ & $71.8^{\mathrm{b}}$ & $25.316^{b}$ & $3.185^{a}$ & $36.68^{a}$ & $17.49^{b}$ & $1.969^{b}$ & $7.641^{b}$ \\
\hline HG-867 & $71.1^{\mathrm{a}}$ & $75.4^{\mathrm{a}}$ & $31.622^{\mathrm{a}}$ & $4.270^{\mathrm{b}}$ & $33.67^{b}$ & $20.54^{a}$ & $4.396^{a}$ & $12.030^{a}$ \\
\hline
\end{tabular}

H: Height, Fl (NO): Number of flower/ plant, S. P: Seed/plant, B: Biomass, Gum\%: Gum Percent, RL: Root Length, BCF (Pb): Bioconcentration factor (Pb), $\mathrm{BCF}(\mathrm{Cd})$ : Bioconcentration factor (Cd). 
Table 5. Correlation analysis among studied traits in different guar varities under various $\mathrm{Pb}$ and $\mathrm{Cd}$.

\begin{tabular}{|c|c|c|c|c|c|c|c|c|c|c|c|c|c|c|c|c|}
\hline Traits & $\mathrm{H}$ & $\begin{array}{l}\mathrm{Br} \\
\text { (NO) }\end{array}$ & $\begin{array}{l}\mathrm{FI} \\
\text { (NO) }\end{array}$ & $\begin{array}{l}\text { Clu } \\
\text { (NO) }\end{array}$ & $\stackrel{\mathrm{L}}{\text { (NO) }}$ & $\mathrm{CH}$ & P. L & $\begin{array}{l}\text { S } \\
\text { (NO) }\end{array}$ & $\begin{array}{l}\text { P } \\
\text { (NO) }\end{array}$ & S. Y & $50 \% \mathrm{P}$ & $\begin{array}{l}\text { W } \\
100 \mathrm{~s}\end{array}$ & B & $R L$ & Gum\% & $\begin{array}{l}\text { Cd } \\
\text { TF }\end{array}$ \\
\hline $\mathrm{H}$ & 1 & & & & & & & & & & & & & & & \\
\hline $\begin{array}{l}\mathrm{Br} \\
\text { (NO) }\end{array}$ & $.680^{\star *}$ & 1 & & & & & & & & & & & & & & \\
\hline $\begin{array}{l}\mathrm{FI} \\
\text { (NO) }\end{array}$ & $.594^{\star \star}$ & $.460^{\star \star}$ & 1 & & & & & & & & & & & & & \\
\hline $\begin{array}{l}\text { Clu } \\
\text { (NO) }\end{array}$ & $.639^{\star \star}$ & $.634^{\star \star}$ & $.769^{\star \star}$ & 1 & & & & & & & & & & & & \\
\hline$\stackrel{\mathrm{L}}{\text { (NO) }}$ & $.564^{\star *}$ & $.576^{* *}$ & $.466^{\star *}$ & $.592^{\star \star}$ & 1 & & & & & & & & & & & \\
\hline $\mathrm{CH}$ & .103 & $.316^{\star *}$ & -.149 & -.093 & .081 & 1 & & & & & & & & & & \\
\hline P. L & $.450^{\star \star}$ & $.500^{\star \star}$ & $.299^{\star *}$ & $.399^{\star *}$ & $.291^{\star *}$ & .190 & 1 & & & & & & & & & \\
\hline $\begin{array}{l}\text { S } \\
\text { (NO) }\end{array}$ & $.433^{\star \star}$ & $.481^{\star \star}$ & $.345^{\star *}$ & $.462^{\star \star}$ & $.282^{\star \star}$ & .163 & $.898^{\star *}$ & 1 & & & & & & & & \\
\hline $\begin{array}{l}\text { P } \\
\text { (NO) }\end{array}$ & $.672^{\star *}$ & $.385^{\star *}$ & $.434^{\star *}$ & $.261^{*}$ & $.219^{\star}$ & $.236^{*}$ & $.298^{\star \star}$ & $.245^{\star \star}$ & 1 & & & & & & & \\
\hline S. Y & $.719^{\star \star}$ & $.436^{\star \star}$ & $.500^{\star \star}$ & $.359^{\star \star}$ & $.253^{\star}$ & $.203^{*}$ & $.448^{\star \star}$ & $.438^{\star \star}$ & $.969^{\star \star}$ & 1 & & & & & & \\
\hline $\begin{array}{l}50 \\
\% \mathrm{P}\end{array}$ & .124 & -.056 & .184 & .052 & .044 & -.151 & .033 & -.009 & $.279^{\star \star}$ & $.288^{\star \star}$ & 1 & & & & & \\
\hline $\begin{array}{l}W \\
100 \\
S\end{array}$ & $.313^{\star \star}$ & $.323^{\star \star}$ & .079 & .150 & $.251^{*}$ & $.288^{\star *}$ & .151 & .186 & $.297^{\star \star}$ & $.294^{\star \star}$ & -.088 & 1 & & & & \\
\hline B & $.656^{\star \star}$ & $.551^{\star \star}$ & $.596^{\star \star}$ & $.586^{\star *}$ & $.601^{\star \star}$ & .004 & $.260^{\star}$ & $.270^{\star \star}$ & $.369^{\star *}$ & $.410^{\star \star}$ & .086 & .006 & 1 & & & \\
\hline RL & $.734^{\star *}$ & $.700^{\star \star}$ & $.641^{\star *}$ & $.591^{\star *}$ & $.611^{\star *}$ & $.251^{*}$ & $.374^{\star *}$ & $.351^{\star *}$ & $.524^{\star \star}$ & $.551^{\star \star}$ & .007 & $.277^{\star *}$ & $.698^{\star *}$ & 1 & & \\
\hline G\% & $.317^{\star \star}$ & $.301^{\star \star}$ & $.234^{\star *}$ & $.222^{\star}$ & $.241^{*}$ & -.027 & .176 & .187 & $.266^{\star \star}$ & $.282^{\star \star}$ & .141 & $.373^{\star \star}$ & .110 & $.252^{*}$ & 1 & \\
\hline $\begin{array}{l}\text { Cd } \\
\text { TF }\end{array}$ & .088 & -.013 & .037 & .008 & .049 & -.037 & -.048 & -.049 & .001 & .008 & -.061 & .014 & .035 & -.112 & .024 & 1 \\
\hline $\begin{array}{l}\text { BCF } \\
\text { Cd }\end{array}$ & -.007 & -.002 & -.008 & .013 & .010 & -.108 & .094 & .119 & .011 & .047 & -.089 & .017 & -.027 & .040 & .074 & .137 \\
\hline $\begin{array}{l}\mathrm{Pb} \\
\mathrm{TF}\end{array}$ & .013 & -.075 & -.056 & -.161 & -.110 & .099 & .008 & -.051 & $.302^{\star \star}$ & $.263^{\star \star}$ & $.315^{\star \star}$ & .069 & -.009 & -.004 & .085 & -.035 \\
\hline $\begin{array}{l}\mathrm{BCF} \\
\mathrm{Pb}\end{array}$ & -.058 & .053 & -.057 & -.004 & .017 & -.075 & .065 & .032 & -.090 & -.077 & -.084 & -.011 & -.046 & .019 & .053 & -.023 \\
\hline
\end{tabular}

$\mathrm{H}$ : Height, $\mathrm{Br}(\mathrm{NO})$ : Number of Branches, Fl (NO): Number of flowers, Clu (NO): Number of Clusters, L (NO): Number of Leave, CH: Chlorophyll, P. L: Pod Length Seeds,

P (NO): Number of pods, S. Y: Seed yield, 50\% p: 50\% poding, W 100 S: Weight of 100 seeds, B: Biomass, Gum\%: Gum Percent, RL: Root length, Cd TF: Transle BCF Cd: Bioconcentration factor (Cd), Pb TF: Translocation factor (Pb), BCF Pb: Bioconcentration factor (Pb).

Table 6. PCA table of the Roselle landraces and genotypes under Pb and Cd application.

\begin{tabular}{llll}
\multicolumn{4}{l}{ Explained Variance (Eigenvalue) } \\
\hline Value & Eigenvalue & $\%$ of Variance & Cumulative\% \\
\hline PC1 & 6.593 & 31.394 & 31.394 \\
\hline PC2 & 2.200 & 10.475 & 41.869 \\
\hline PC3 & 1.950 & 9.285 & 51.154 \\
\hline PC4 & 1.386 & 6.598 & 57.752 \\
\hline PC5 & 1.350 & 6.430 & 64.182 \\
\hline PC6 & 1.139 & 5.425 & 69.607
\end{tabular}




\begin{tabular}{|c|c|c|c|c|c|c|c|c|c|}
\hline Components loadings & PC1 & PC2 & PC3 & PC4 & Components loadings & PC1 & PC2 & PC3 & PC4 \\
\hline Height & .888 & -.138 & .017 & .034 & $50 \% \mathrm{p}$ & .144 & -.474 & .337 & -.400 \\
\hline $\mathrm{Br}(\mathrm{NO})$ & .785 & .275 & -.093 & .046 & $50 \% f$ & .279 & .570 & .004 & .041 \\
\hline $\mathrm{Fl}$ (NO) & .752 & -.294 & -.286 & -.154 & W $100 \mathrm{~s}$ & .372 & .139 & .293 & .624 \\
\hline Clu (NO) & .762 & -.054 & -.427 & -.108 & B & .710 & -.129 & -.276 & -.268 \\
\hline L (NO) & .669 & .056 & -.327 & .025 & RL & .836 & .049 & -.071 & -.060 \\
\hline $\mathrm{CH}$ & .172 & .511 & .459 & .135 & Gum\% & .392 & -.189 & .143 & .410 \\
\hline L.A & .442 & -.587 & -.171 & .334 & Cd TF & .023 & -.212 & -.151 & .488 \\
\hline P. L & .602 & .540 & .116 & -.162 & BCF Cd & .037 & .060 & -.093 & .319 \\
\hline S (NO) & .603 & .515 & .043 & -.117 & $\mathrm{~Pb} \mathrm{TF}$ & .027 & -.207 & .662 & -.203 \\
\hline$P(\mathrm{NO})$ & .682 & -.276 & .546 & .008 & BCF Cd & -.027 & .136 & -.085 & .006 \\
\hline S. Y & .762 & -.198 & .489 & -.023 & & & & & \\
\hline \multicolumn{10}{|c|}{$\begin{array}{l}\text { H: Height, Br (NO): Number of Branches, FI (NO): Number of flowers, Clu (NO): Number of Clusters, L. A: Leaf Area, CH: Chlorophyll, P. L: Pod Length, S (NO), } \\
\text { Number of Seeds, P (NO): Number of pods, S. Y: Seed yield, }\end{array}$} \\
\hline \multicolumn{10}{|c|}{$50 \%$ p: $50 \%$ poding, $50 \%$ f: $50 \%$ flowering, W 100 S: Weight of 100 seeds, B: Biomass, RL: Root length, } \\
\hline \multicolumn{10}{|c|}{ Gum\%: Gum Percent, Cd TF: Translocation factor (Cd), BCF Cd: Bioconcentration factor (Cd), } \\
\hline \multicolumn{10}{|c|}{ Pb TF: Translocation factor (Pb), BCF Pb: Bioconcentration factor (Pb). } \\
\hline
\end{tabular}

\section{Figures}

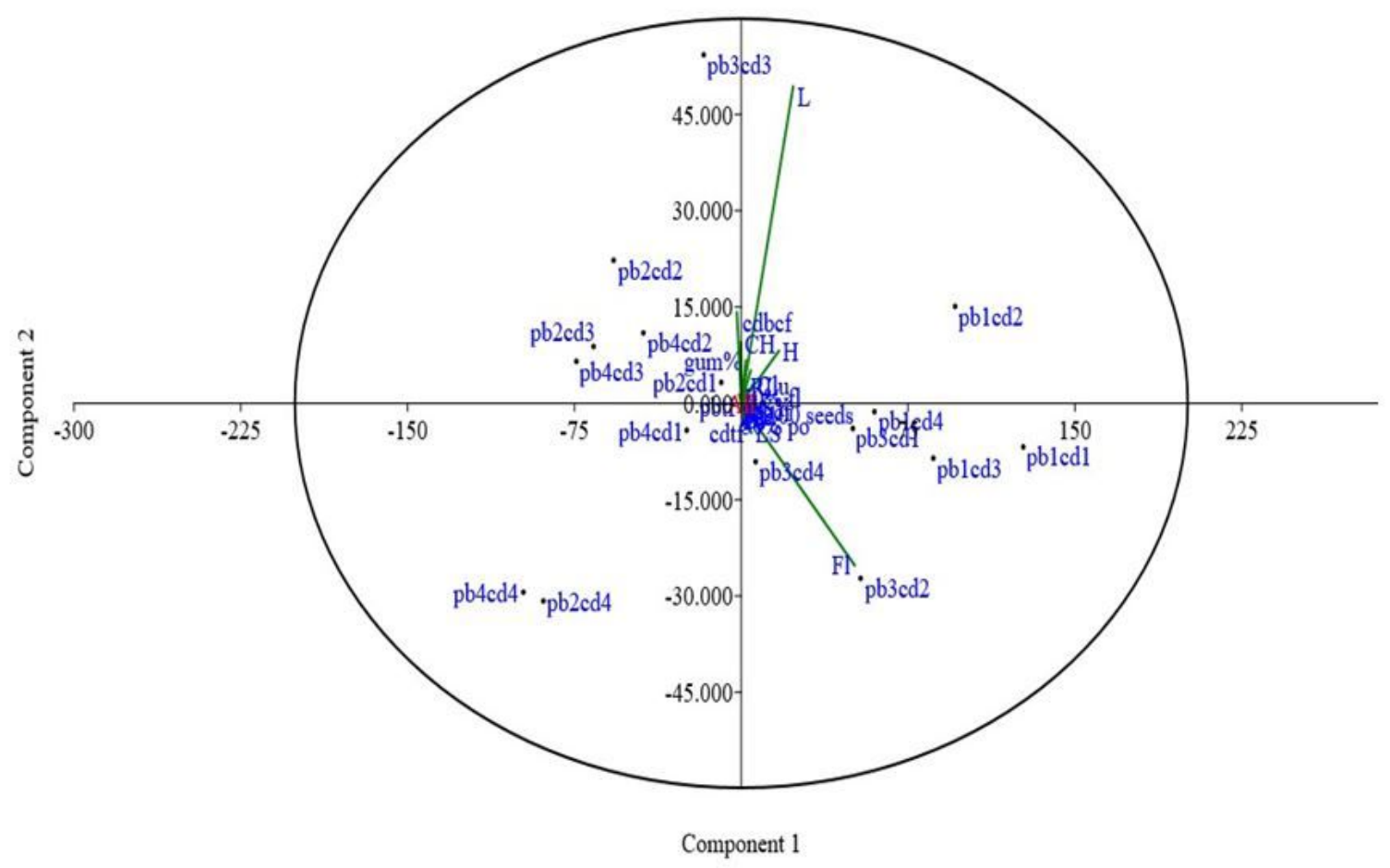

\section{Figure 1}

Biplot of the first two principal components (PC1 and $\mathrm{PC} 2)$ based on the examined parameters which were significant following interaction of $\mathrm{Pb}$ and $\mathrm{Cd}$. 


\section{Distance}

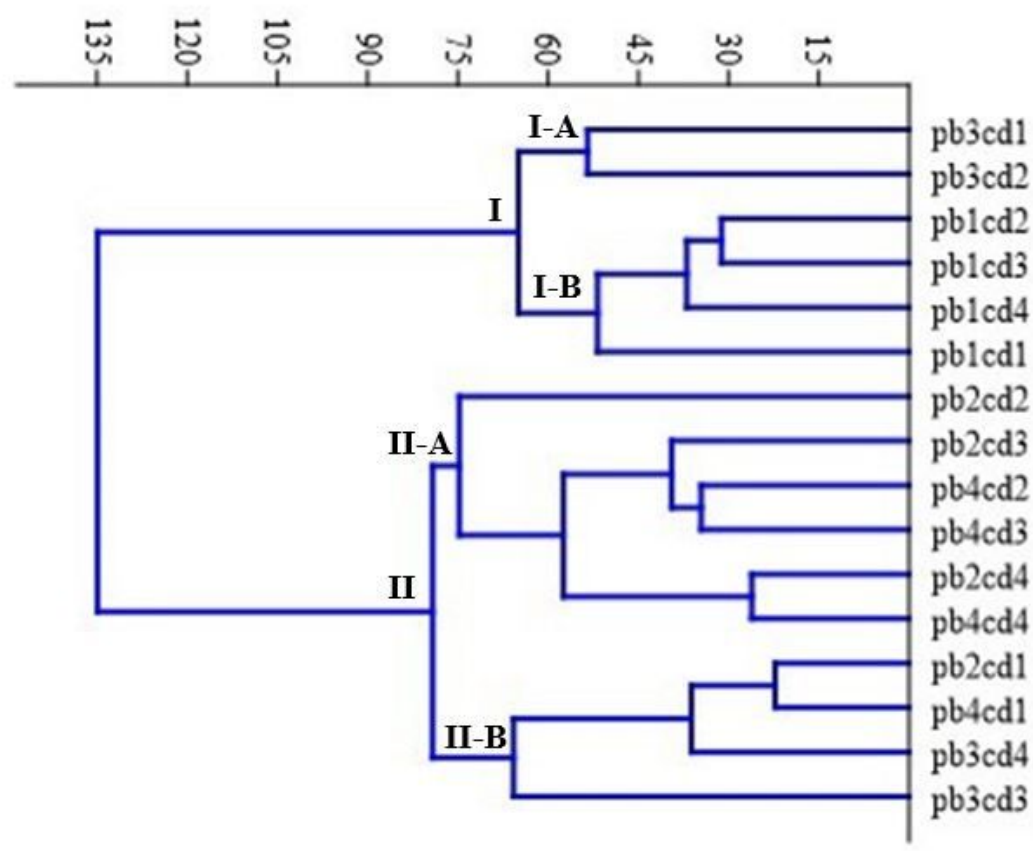

Figure 2

Dendrogram of cluster analysis for the interaction of $\mathrm{Pb}$ and $\mathrm{Cd}$ on investigated traits.

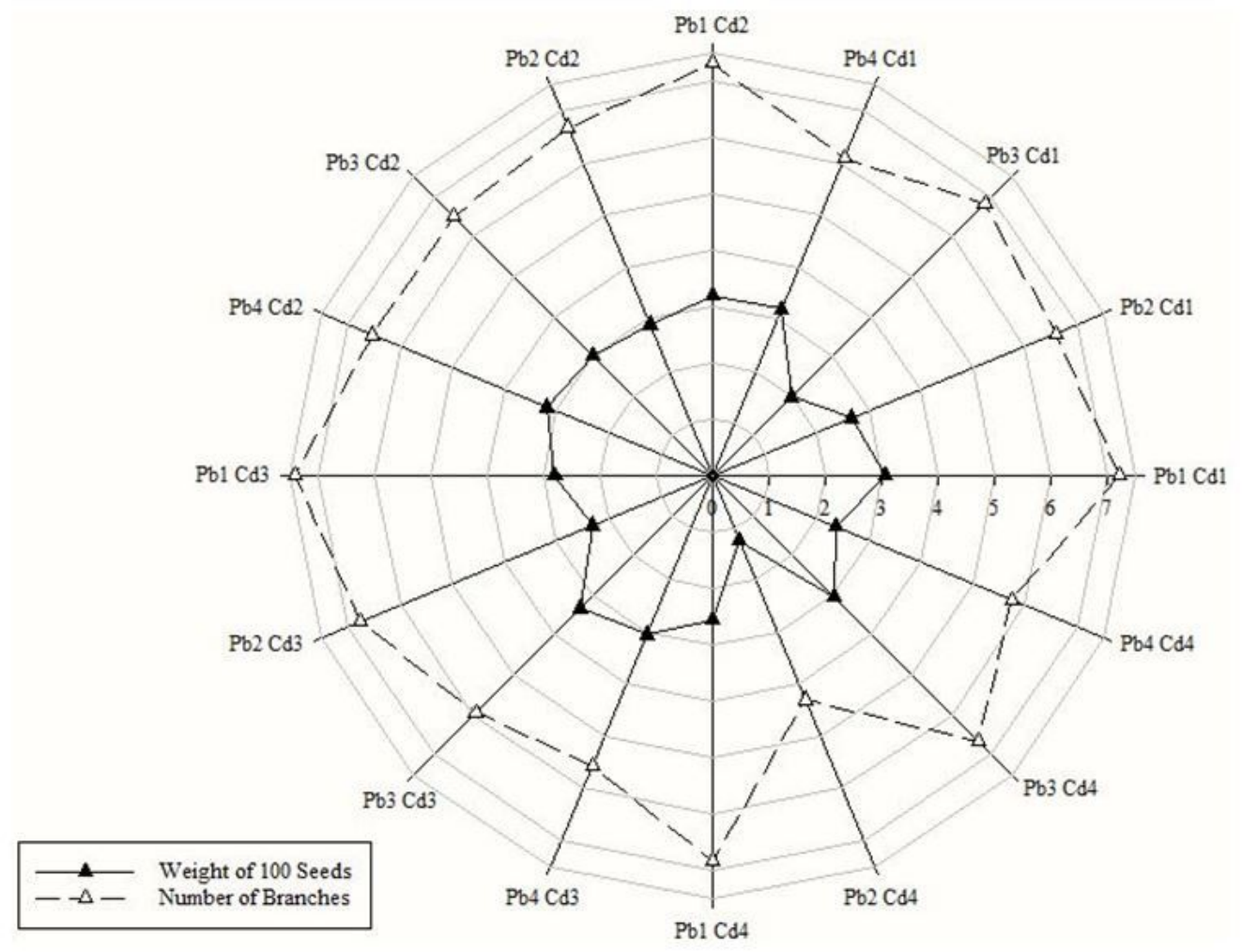

Figure 3

The comparison of the impact of interaction $\mathrm{Pb}$ in $\mathrm{Cd}$ on weight of 100 seeds and number of branches. 


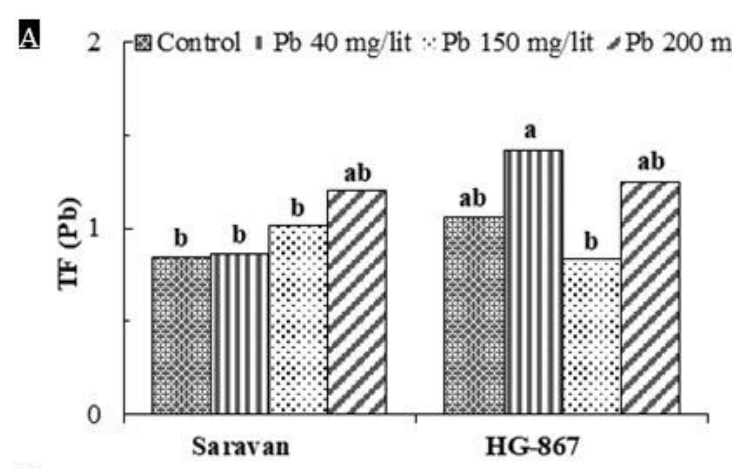

C 4 [e Control । Pb $40 \mathrm{mg} / \mathrm{lit} \because \mathrm{Pb} 150 \mathrm{mg} / \mathrm{lit} r \cdot \mathrm{Pb} 200 \mathrm{mg} / \mathrm{lit}$

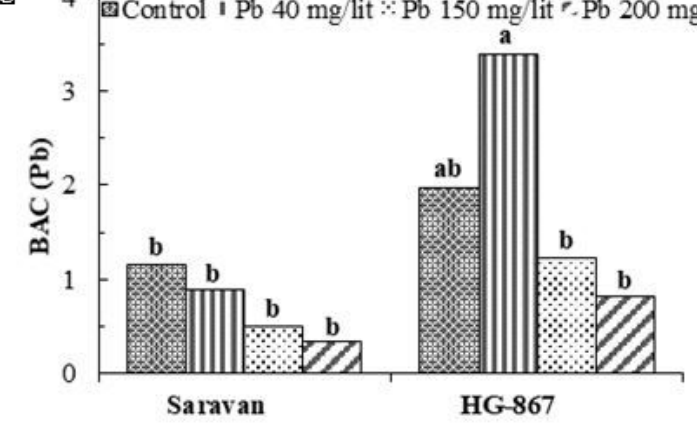

B

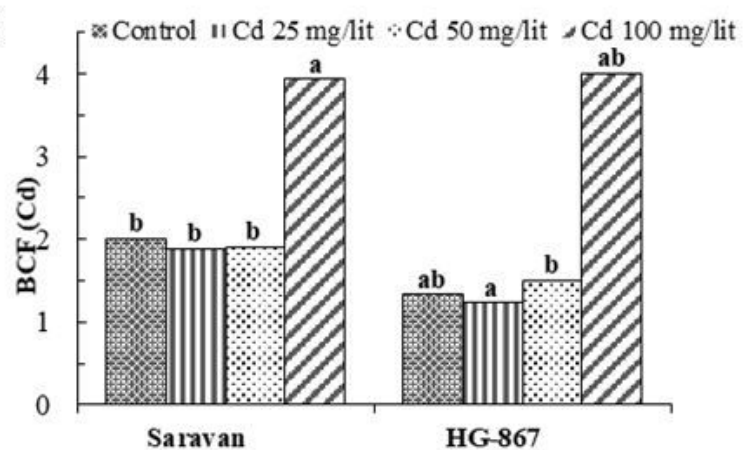

D. 5 [Control $\Perp \mathrm{Pb} 40 \mathrm{mg} /$ lit $\because \mathrm{Pb} 150 \mathrm{mg} /$ lit $r_{\sim} \mathrm{Pb} 200 \mathrm{mg} /$ lit

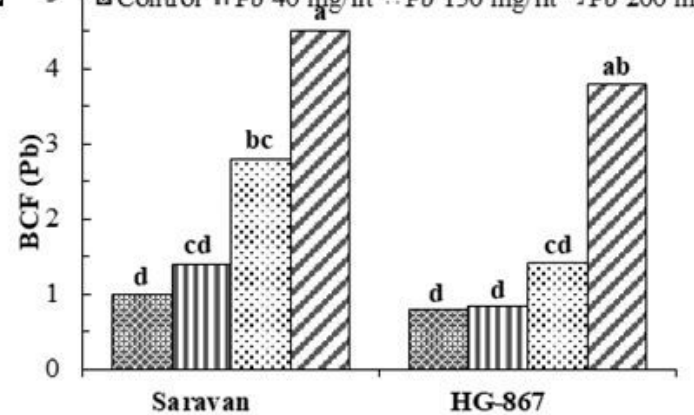

Figure 4

Interaction of genotypes and Pb/Cd on the TF (Pb) (A), BCF (Cd) (B), BAC (Pb) (C) and BCF (Cd).
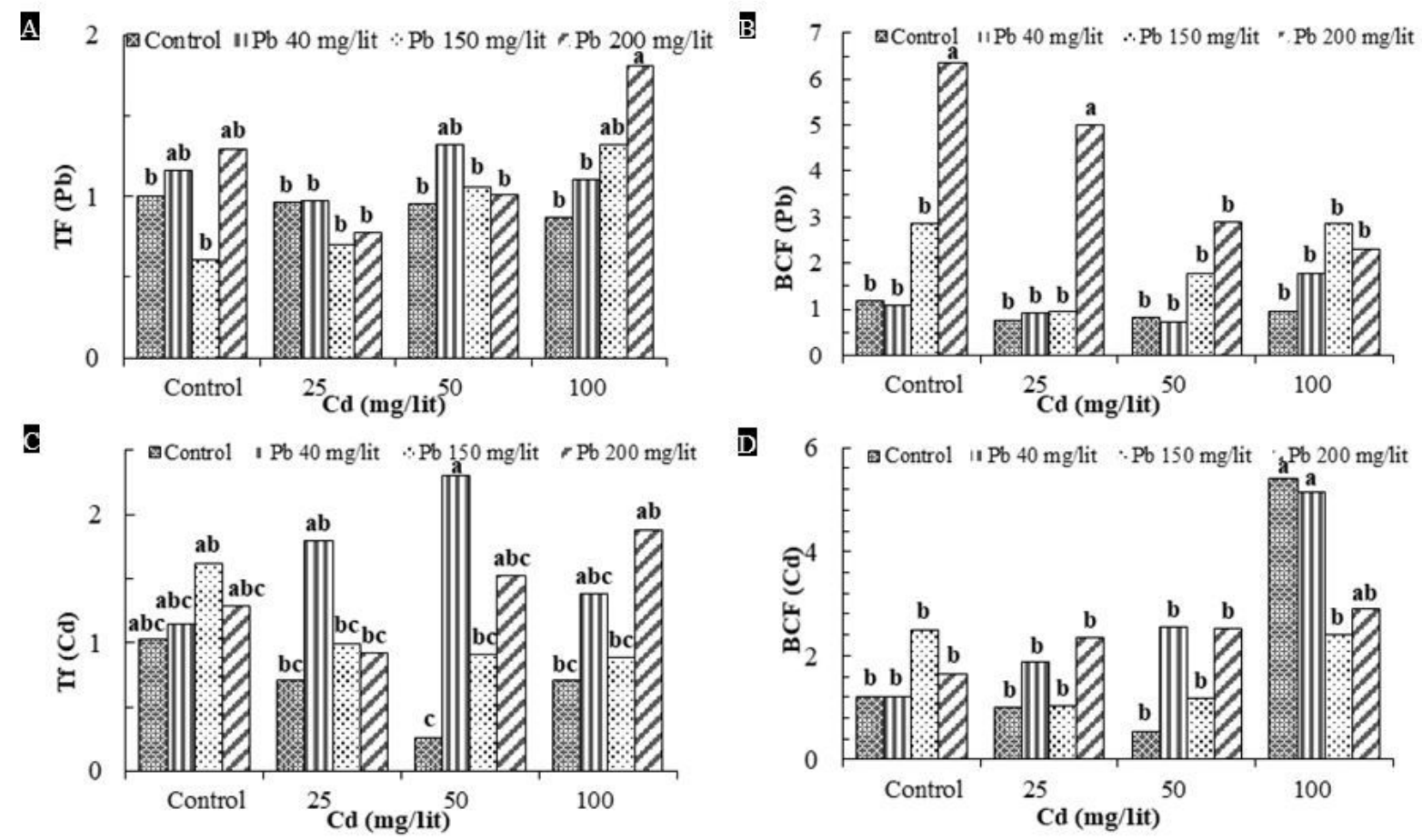

Figure 5

Interaction of $\mathrm{Cd}$ and $\mathrm{Pb}$ on Pbtf (A), bcf $\mathrm{Pb}$ in root (B), $\mathrm{Cd} \mathrm{tf} \mathrm{(C)} \mathrm{and} \mathrm{bcf} \mathrm{Cd}$ in root (D). 

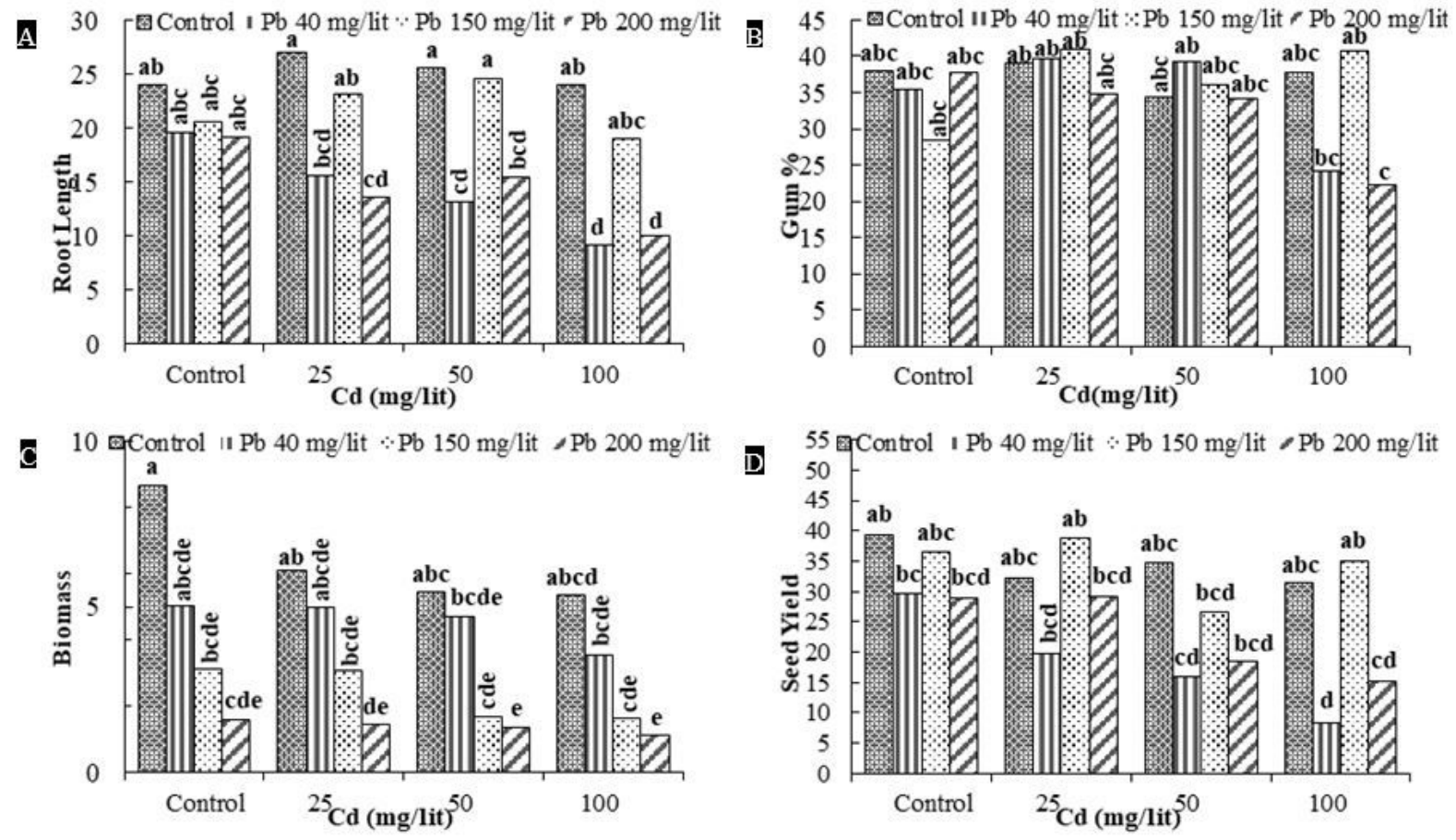

Figure 6

Interaction of $\mathrm{Cd}$ and $\mathrm{Pb}$ on seed yield, biomass, gum\% and root length. 